\title{
Conventional vegetative propagation and in vitro seed germination of endemic plant Colubrina travancorica Bedd
}

\author{
Nisha Joseph ${ }^{1^{*}}$, Vineeth V.K. ${ }^{2}$ \\ ${ }^{1,2}$ Post graduate and Research Department of Botany, Catholicate College, Pathanamthitta, \\ Kerala, India. \\ "Corresponding Author: nishajose2007@gmail.com
}

Available online at: www.isroset.org

Accepted: 23/Aug/2018, Online: 30/Aug/ 2018

\begin{abstract}
Colubrina travancorica Bedd. is a medicinally important endemic plant species of Southern Western Ghats. Scientific studies are lacking due to the non availability of this Rare Endangered and Threatened (RET) species. For the conservation and establishment of $C$. travancorica, propagation methods have to be standardized. In the present study, propagation of the plant is achieved through hard wood cuttings, softwood cuttings and in vitro seed germination with different plant growth regulators. The type of auxins, Indole-3-acetic acid (IAA), Indole-3-butyric acid (IBA) or Naphthalene acetic acid (NAA) at varying concentrations affect the rooting response of hardwood and softwood cuttings. Significantly $(\mathrm{p}<0.001)$ high rooting was observed in hardwood cuttings treated with $2.5 \mathrm{mM}$ IAA (53.3\%). The number of roots (25.16) was significantly $(\mathrm{p}<0.001)$ high in cuttings treated with $0.5 \mathrm{mM}$ NAA. Seasonal variation in the rooting response was observed in both hardwood and softwood cuttings. In soft wood cuttings maximum rooting (26.6\%) was observed in $20 \mathrm{mM}$ IBA treatment. Control set completely failed to root in the soft wood cuttings. Highest in vitro seed germination was achieved with $6.0 \mu \mathrm{M}$ Gibberellic acid. Among the various propagation methods hard wood cuttings are found to be the most suitable material for the propagation of $C$. travancorica and it can be effectively used for the large scale multiplication of this plant.
\end{abstract}

Keywords - Colubrina travancorica Bedd., endemic plant, hardwood cuttings, seed germination, softwood cuttings, rooting.

\section{INTRODUCTION}

According to the World Conservation Union, over 8,000 plant species worldwide are threatened with extinction and that number grows daily. Researchers have recently estimated that between $22 \%$ and $47 \%$ of the world's flora is in serious decline. These are disturbing trends because plants provide essential ecosystem services that sustain life on the planet by producing oxygen, sequestering carbon dioxide, and providing food, medicines, building materials, textiles, and habitat. Many plants listed as in danger are endemic to small regions or require specialized habitats. However, an increasing number of formerly dominant species are rapidly becoming vulnerable. Thus efforts to conserve and manage plants are critically needed around the world. Generally conservation of plants is achieved through its propagation.

The genus Colubrina comprises about 30 species of flowering plants belonging to Rhamnaceae family. Colubrina travancorica, an endemic plant to Southern Western Ghats is one among them. C. travancorica deserves special attention as it is a Rare Endangered and Threatened (RET) species (www.kfri.res.in/downloads/RET_database.xlsx). In India it is found in moist deciduous forests and in sacred grooves. It is a glabourous evergreen shrub, flowering and fruiting takes place from November to March. In Kerala, C. travancorica is distributed mainly in Alappuzha, Pathanamthitta, Thiruvanathapuram, Ernakulum and Thrissur districts [1].

Asian immigrants used Colubrina in traditional medicine and also as soap substitute [2]. In the Bahamas, Colubrina asiatica is used as a digestive aid, antiscorbutic, tonic, laxative, febrifuge, medicinal bath and a vermifuge [3]. A distilled mixture of whole fruits of $C$. asiatica L. is reportedly used as an abortifacient as well as a piscicide and migraine remedy [4]. The essential oil of the fruit has a blood pressure reducing effect and induces spasmolytic activity [5]. A significant cancer inhibiting compounds have been identified and isolated in six New World species of the Genus Colubrina [6].

Even though several species of Colubrina has been used in traditional medicine and in industry, scientific experiments are lacking in Colubrina travancorica. C. travancorica is a medicinally important endemic species which is traditionally used to relieve pain. For the conservation and establishment of species propagation methods are very important. In the present study propagation aspects of Colubrina travancorica has been undertaken as an initial step for the multiplication and conservation of the plant. 
The paper is organized as follows, Section I contains the introduction about the plant and the importance of the work, Section II explains the methodology followed for the vegetative propagation of hardwood cuttings, softwood cuttings, in vitro seed germination with details of statistical analysis, Section III describes results in the rooting of hardwood cuttings, rooting response of softwood cuttings, seed viability and germination rates of in vitro grown seeds and discussion, Section IV concludes research work with future directions.

\section{MATERIALS AND METHODS}

The plant materials were collected from Kottarakkara, Kerala $\left(08^{\circ} 59^{\prime} 00^{\prime \prime} \mathrm{N}, 7^{\circ} 46^{\prime} 00^{\prime \prime} \mathrm{E}\right)$. The vegetative propagation experiments were conducted in two different seasons viz. November-December (Season 1) and July-August (Season 2 ). The collected cuttings were pooled and divided into groups, each with 10 cuttings.

\section{Vegetative propagation by hard wood cuttings}

Uniform cuttings of about $25 \mathrm{~cm}$ long were excised from the basal part of selected branches were collected, pooled and divided into ten groups, each with 10 cuttings. The leaves and tip portion of each branch was removed prior to indole3-acetic acid (IAA), Indole-3-butyric acid (IBA) and Naphthalene acetic acid (NAA) treatment, at $0.5 \mathrm{mM}, 2.5$ $\mathrm{mM}$, and $5.0 \mathrm{mM}$ concentrations. Cuttings dipped in distilled water are kept as control. Cuttings were dipped in each auxin solution for $24 \mathrm{~h}$. The auxin treated cuttings were then planted in nursery beds of $10 \mathrm{~m} \times 2.5 \mathrm{~m}$ filled with soil. At three months (90 days) after planting, the cuttings were uprooted and observations on the percentage of rooting, the number of shoots per cutting, the shoot length per cutting (cm), number of leaf per cutting, the number of roots per cutting and the root length per cutting $(\mathrm{cm})$ were made and are photographed.

\section{Vegetative propagation by soft wood cuttings}

Soft wood cuttings of current season growth with a shoot tip of $10 \mathrm{~cm}$ length were excised from source plants and were rapidly placed in wet polyethylene bags. Each leaf was cut in half and the cuttings were arranged in bundles, each of 10 cuttings were treated for $5 \mathrm{~min}$ in $5.0 \mathrm{mM}, 10 \mathrm{mM}$, and 20 $\mathrm{mM}$ concentration of IAA, IBA, and NAA. The basal 2-3 $\mathrm{cm}$ portion of each cutting was dipped in each auxin solution. Cuttings dipped in distilled water served as control. The cuttings were then planted in plastic cups (diameter $=15 \mathrm{~cm}$; height $=8 \mathrm{~cm}$ ) containing 1: 1 mixture of sand and soil. The cuttings were irrigated regularly. Two months after planting (60 days), observations on the percentage of rooting, the number of shoots per cutting, the number of roots per cutting, the root length per cutting $(\mathrm{cm})$ and number of new root buds (roots with less than $0.5 \mathrm{~cm}$ length) were made.

\section{Seed viability test and In vitro germination}

The viability of seed was tested by Triphenyl Tetrazolium Chloride test or TTC (2-3-5-Triphenyl Tetrazolium Chloride) test. Living tissues in TTC solution produce insoluble red compound Formazan because of the presence of dehydrogenase enzyme. For the Tetrazolium test, $1 \%$ test solution of $\mathrm{pH}$ 6.5-7.5 was prepared by dissolving $1 \mathrm{gm}$ of 23-5-Triphenyl Tetrazolium Chloride in the phosphate buffer solution.

For in vitro germination of seed, the fully matured dry fruits were collected during seed maturation (March). The fruits cut open at the time of sterilization process. For the four step sterilization process the seeds were first wiped with ethyl alcohol and then washed in running tap water followed by Tween 20 and Savlon treatment (2-3 drops in $100 \mathrm{ml}$ distilled water) for 5 minutes. The mercuric chloride $(0.2 \%)$ treatment was only carried out within the laminar airflow chamber for 5 minutes.

MS medium [7] containing 3\% (w/v) sucrose (87.6 mM) and $0.7 \%$ agar was used. Plant growth regulator Gibberellic acid (GA3) at different concentrations were incorporated into the culture medium. The $\mathrm{pH}$ of the medium was adjusted to 5.8 before autoclaving at $121^{\circ} \mathrm{C}$ and $1.05 \mathrm{~kg} / \mathrm{cm} 2$ pressure for 15 min. After sterilization process, the seeds were inoculated in M.S medium modified by the addition of GA3 in $1.5 \mu \mathrm{M}, 3.0$ $\mu \mathrm{M}, 4.5 \mu \mathrm{M}$, and $6.0 \mu \mathrm{M}$ concentrations. Each treatment contains ten culture tubes. One set of seeds inoculated in basal medium without hormone served as control. The cultures were incubated at $25 \pm 2^{\circ} \mathrm{C}$ in a culture room with $50 \mu \mathrm{molm}^{-2} \mathrm{~s}^{-2}$ irradiance provided by cool fluorescent tubes (40 W; Philips, India) and were exposed to a photoperiod of $16 \mathrm{~h}$ and $55 \pm 5 \%$ of relative humidity $(\mathrm{RH})$. After four week's incubation period the percentage of germinated seeds were recorded.

\section{Statistical analysis}

All the experiments were conducted using a completely randomized block design. Every treatment was composed of three replications and each replication block was represented by ten cuttings or seeds. Data on various parameters were subjected to one-way analysis of variance (ANOVA). Means separation was performed using Duncan New Multiple Range Test $(\mathrm{p}<0.05)$.

\section{RESULTS}

\section{Rooting response of hardwood cuttings}

The rooting response in the hard wood cuttings of $C$. travancorica showed significant $(\mathrm{p}<0.001)$ response on treatment with various auxins (Table 1). Controls without any auxin treatment have a very low percentage of rooting 
(3.3\%) and shooting (Figure 1 a). In the first season, the highest rooting percentage $(53.3 \%)$ was recorded in $2.5 \mathrm{mM}$ IAA (Figure $1 \mathrm{c}$ ) treated cuttings, followed by $0.5 \mathrm{mM}$ IBA
(33.3\%) and $2.5 \mathrm{mM}$ NAA $(30.0 \%)$ treated cuttings. The number of shoots and shoot length was significantly $(\mathrm{p}<0.001)$ high in cutting treated with $0.5 \mathrm{mM}$ IAA and

Table 1: Effect of various auxins on shoot formation and the rooting response of hard wood cuttings of Colubrina ravancorica Bedd. (Season 1).

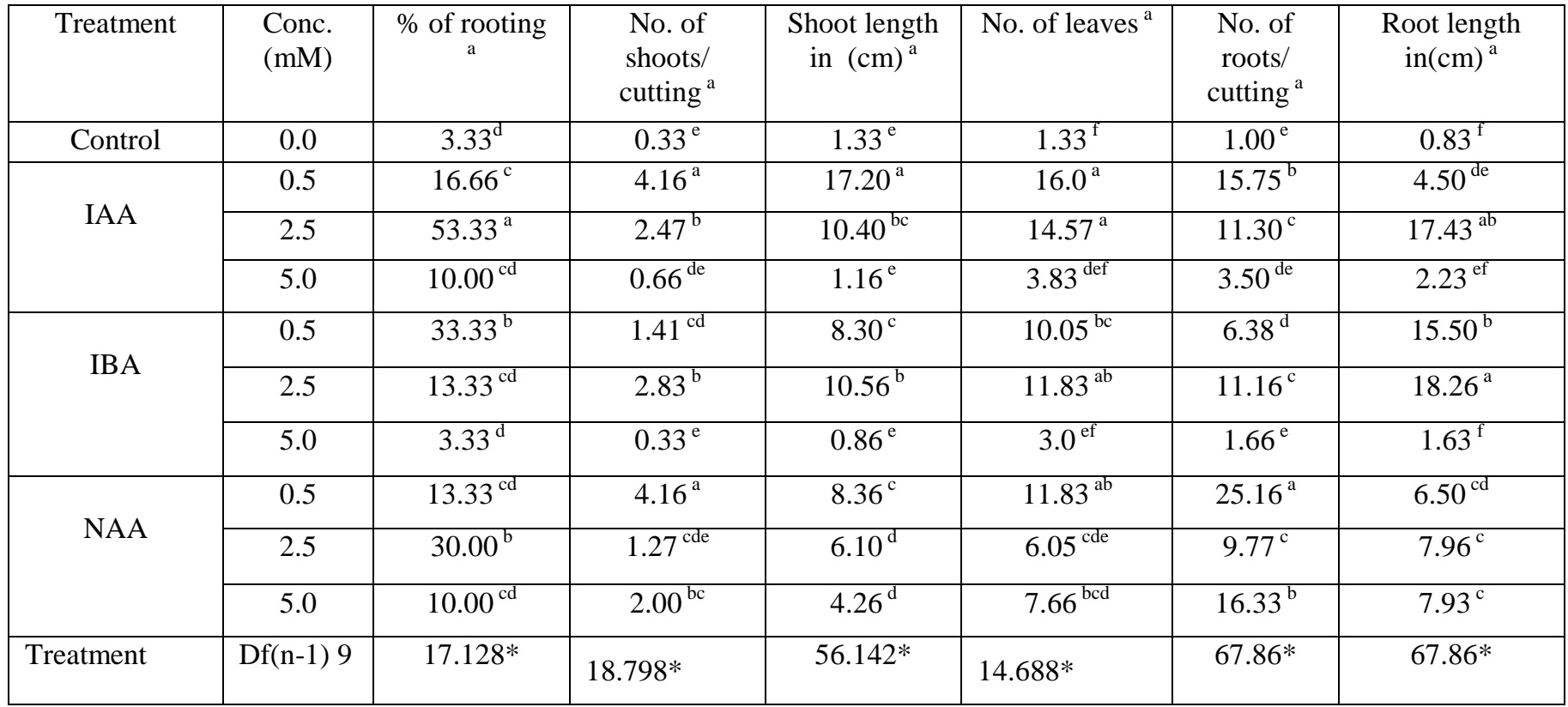

${ }^{a}$ Means with in column followed by same letters are not significantly $(\mathrm{p}<0.05)$ different as determined by Duncan's New Multiple range Test (DNMRT). *Significant at $\mathrm{p}<0.001$ level.

NAA. Shoot length was found to be high in $0.5 \mathrm{mM}$ IAA (Figure 1b). But root length was relatively large $(18.26 \mathrm{~cm})$ in cuttings treated with $2.5 \mathrm{mM}$ IBA (Figure 1d) treatment followed by $2.5 \mathrm{mM}$ NAA treated cuttings. Whereas the number of roots $(25.16)$ was significantly $(\mathrm{p}<0.001)$ high in cuttings treated with $0.5 \mathrm{mM}$ NAA (Figure $1 \mathrm{e}$ ). The high concentration of IAA and IBA inhibited the rooting and shooting.
In the second season, the hard wood cutting showed rooting only in cuttings treated with 0.5 and $2.5 \mathrm{mM}$ IAA (Table 2). The treated concentrations of IBA and NAA did not stimulate rooting and shooting. Among the different IAA concentrations, maximum rooting $(20.0 \%)$, number of shoots (2.10), shoot length $(10.50 \mathrm{~cm})$ and root length $(16.83)$ were observed in $2.5 \mathrm{mM}$ IAA. The control set completely failed to root.

Table 2: Effect of IAA on shoot formation and the rooting response of hard wood cuttings of C. travancorica Bedd (Season 2).

\begin{tabular}{|c|c|c|c|c|c|c|c|}
\hline Treatment & $\begin{array}{c}\text { Conc. } \\
(\mathrm{mM})\end{array}$ & $\begin{array}{c}\text { \% of } \\
\text { rooting }^{\mathrm{a}}\end{array}$ & $\begin{array}{c}\text { No of } \\
\text { shoot }^{\mathrm{a}}\end{array}$ & $\begin{array}{c}\text { Shoot } \\
\text { length }(\mathrm{cm}) \\
\mathrm{a}\end{array}$ & $\begin{array}{c}\text { No of leaf } \\
\mathrm{a}\end{array}$ & $\begin{array}{c}\text { No of root } \\
\mathrm{a}\end{array}$ & $\begin{array}{c}\text { Root length } \\
(\mathrm{cm})^{\mathrm{a}}\end{array}$ \\
\hline \multirow{2}{*}{ Control } & 0 & $0.0^{\mathrm{c}}$ & $0.0^{\mathrm{b}}$ & $0.0^{\mathrm{b}}$ & $0.0^{\mathrm{b}}$ & $0.0^{\mathrm{b}}$ & $0.0^{\mathrm{b}}$ \\
\hline \multirow{2}{*}{ IAA } & 0.5 & $13.33^{\mathrm{ab}}$ & $1.83^{\mathrm{a}}$ & $8.56^{\mathrm{a}}$ & $12.33^{\mathrm{a}}$ & $12.33^{\mathrm{a}}$ & $14.86^{\mathrm{a}}$ \\
\cline { 2 - 8 } & 2.5 & $20.00^{\mathrm{a}}$ & $2.10^{\mathrm{a}}$ & $10.50^{\mathrm{a}}$ & $13.03^{\mathrm{a}}$ & $12.0^{\mathrm{a}}$ & $16.83^{\mathrm{a}}$ \\
\cline { 2 - 8 } & 5.0 & $3.33^{\mathrm{bc}}$ & $0.33^{\mathrm{b}}$ & $1.73^{\mathrm{b}}$ & $1.66^{\mathrm{b}}$ & $2.33^{\mathrm{b}}$ & $2.93^{\mathrm{b}}$ \\
\hline Treatment & Df(n-1) 3 & $6.06^{*}$ & $11.62^{* *}$ & $29.15^{* *}$ & $43.47^{* *}$ & $28.02^{* *}$ & $28.331^{* *}$ \\
\hline
\end{tabular}

a Means with in column followed by same letters are not significantly $(\mathrm{p}<0.05)$ different as determined by Duncan's New Multiple range Test (DNMRT). **Significant at $\mathrm{p}<0.001$ level, *significant at $\mathrm{p}<0.01$ level. 


\section{Rooting response of soft wood cuttings}

In softwood cuttings, rooting is observed only in Season 2. The rooting response of soft wood cuttings showed significant $(\mathrm{p}<0.001)$ effect with different concentrations of IBA treatment (Table 3). Maximum rooting (26.66\%) was observed in cuttings treated with $20 \mathrm{mM}$ IBA (Figure $1 \mathrm{f}$ ).
Significantly $(\mathrm{p}<0.001)$ high number of roots $(8.0)$ and 19.66 root buds (root with less than $0.5 \mathrm{~cm}$ ) was also observed in this concentration (Table 3 ). The control set completely failed to root. IAA and NAA treatment did not produce any rooting in soft wood cuttings.

Table 3: Effect of IBA on shoot formation and the rooting response of soft wood cuttings of $C$. travancorica Bedd.

\begin{tabular}{|c|c|c|c|c|c|c|c|}
\hline Treatment & $\begin{array}{c}\text { Con. } \\
(\mathrm{mM})\end{array}$ & \% of rooting & $\begin{array}{c}\text { No of } \\
\text { shoot }\end{array}$ & $\begin{array}{c}\text { No of } \\
\text { leaf }^{\mathrm{a}}\end{array}$ & $\begin{array}{c}\text { No of } \\
\text { root }^{\mathrm{a}}\end{array}$ & $\begin{array}{c}\text { Root length } \\
\text { (cm }^{\mathrm{a}}\end{array}$ & $\begin{array}{c}\text { No of new } \\
\text { root buds }^{\mathrm{a}}\end{array}$ \\
\hline \multirow{2}{*}{ Control } & 0.0 & $0.0^{\mathrm{b}}$ & $0.0^{\mathrm{c}}$ & $0.0^{\mathrm{b}}$ & $0.0^{\mathrm{c}}$ & $0.0^{\mathrm{c}}$ & $0.0^{\mathrm{b}}$ \\
\hline \multirow{3}{*}{ IBA } & 5 & $0.0^{\mathrm{b}}$ & $0.0^{\mathrm{c}}$ & $0.0^{\mathrm{b}}$ & $0.0^{\mathrm{c}}$ & $0.0^{\mathrm{c}}$ & $0.0^{\mathrm{b}}$ \\
\cline { 2 - 8 } & 10 & $6.66^{\mathrm{b}}$ & $0.66^{\mathrm{b}}$ & $0.66^{\mathrm{a}}$ & $3.33^{\mathrm{b}}$ & $3.93^{\mathrm{b}}$ & $0.0^{\mathrm{b}}$ \\
\cline { 2 - 8 } & 20 & $26.66^{\mathrm{a}}$ & $1.30^{\mathrm{a}}$ & $1.0^{\mathrm{a}}$ & $8.0^{\mathrm{a}}$ & $7.5^{\mathrm{a}}$ & $19.66^{\mathrm{a}}$ \\
\hline Treatment & $\begin{array}{c}\mathrm{Df}(\mathrm{n}-1) \\
3\end{array}$ & $28.66^{*}$ & $11.03^{*}$ & $9.00^{*}$ & $16.64^{*}$ & $12.27^{*}$ & $497.28^{*}$ \\
\hline
\end{tabular}

a Means with in column followed by same letters are not significantly $(\mathrm{p}<0.05)$ different as determined by Duncan's New Multiple range Test (DNMRT). *Significant at $\mathrm{p}<0.001$ level.

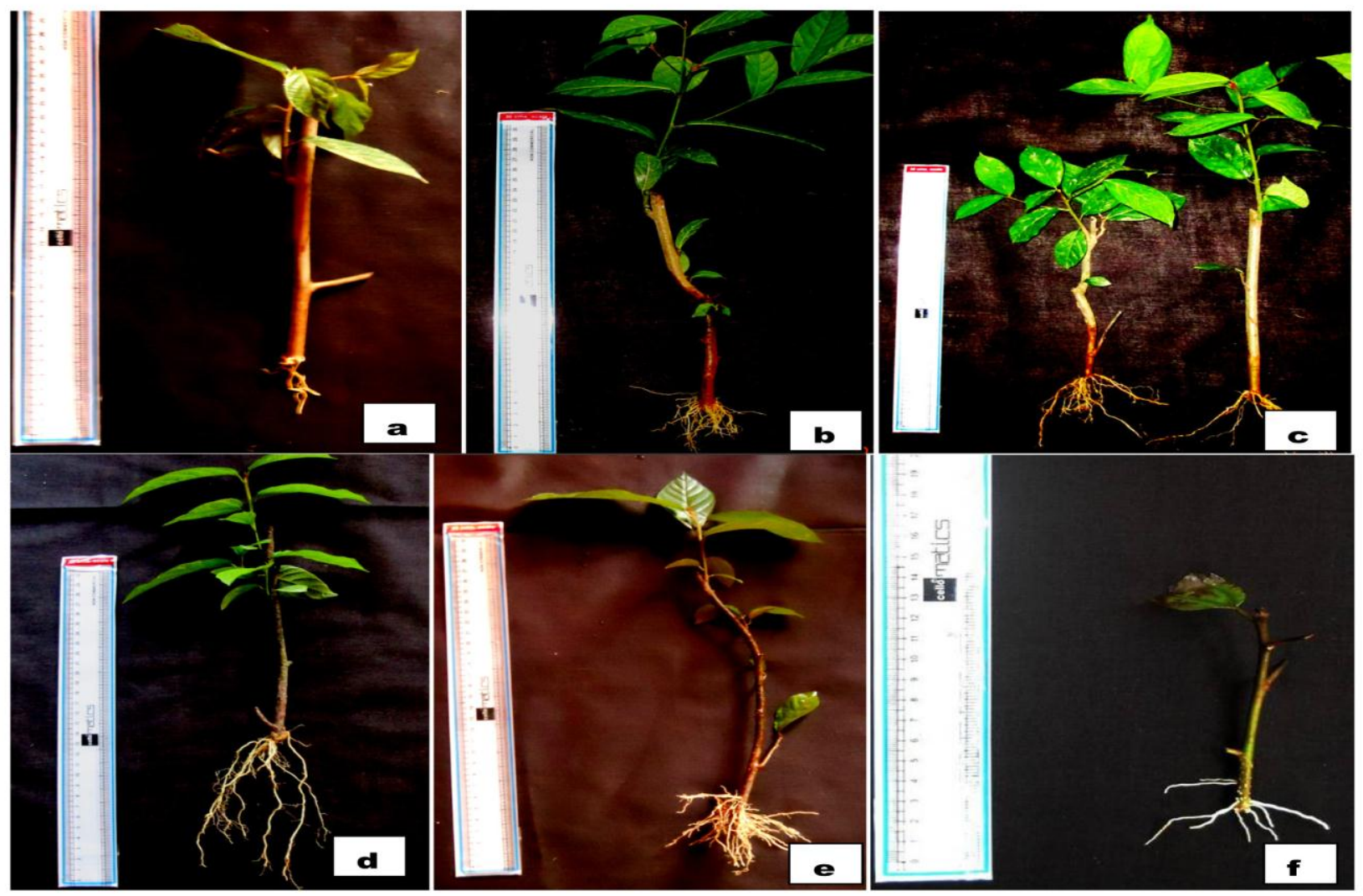

Figure 1 Vegetative propagation of Colubrina travancorica. a-e) Rooting of hard wood cuttings treated with different auxins a) control b) IAA $0.5 \mathrm{mM}$ c) IAA $2.5 \mathrm{mM}$ d) IBA $2.5 \mathrm{mM}$ e) NAA $0.5 \mathrm{mM}$ f) Rooting of softwood cutting treated with $20 \mathrm{mM}$ IBA 


\section{Seed viability and in vitro seed germination}

The seed viability of $C$. travancorica was tested by TTC test. The result showed that only $30 \%$ of the seeds are fully coloured; that denote the good viable seeds, and $30 \%$ of the seeds with uncoloured spots denoting seeds with declining viability. The necrotic areas on $40 \%$ seeds indicate the non viability of seeds.

The in vitro seed germination result showed that the effect of GA3 in seed germination of $C$. travancorica. Maximum seed germination percentage $(30 \%)$ and rapid seed germination was observed in media supplemented with high concentration of GA3 $(6.0 \mu \mathrm{M})$ followed by $4.5 \mu \mathrm{M}$ GA3 $(20 \%)$. No seed germination was observed in the control set and in media supplemented with low concentration of GA3.

\section{Discussion}

In the present study, growth hormones had a promoting effect on rooting of cuttings. The hardwood cuttings of $C$. travancorica showed that low concentration of IAA and IBA $(0.5$ and $2.5 \mathrm{mM})$ promote the development of root and shoot. The high concentration of the tested auxins $(5 \mathrm{mM})$ had inhibitory effect in root and shoot formation. In the elongation of shoots the IAA had significant effect. The suitability of IAA to elicit rooting in hard wood cuttings of Bixa orellana L. has been reported [8]. NAA significantly increase the number of primary roots and total root length in Abies franseri [9]. Similar effect of increased number of roots was observed in NAA treatment of $C$. travancorica but root length was longer in cuttings treated with IAA and IBA. In the present study, rooting of cutting is difficult without using rooting hormones. The establishment and growth rate of cutting depends upon many factors like season of cutting, age and portion of the branch, growth media, moisture and nutrient status [10]. In the present study also, seasonal differences affect the rooting response of cuttings. For hard wood cuttings maximum rooting was observed in November - December. Seasonal variation may be due to varying level of internal plant hormones in different seasons.

Effect of growth hormones in soft wood cuttings of Lawsonia and Camellia was showed that IBA treatments showed maximum rooting percentage, maximum shoot length, and maximum plant survival $[11,12]$. Similar results were observed in $C$. travancorica softwood cuttings. The differential response of softwood and hardwood cuttings to different auxins might be due to different ratios of endogenous root promoting substances in each type of cuttings. This may be explained by the greater accumulation of reserves in hardwood cuttings [13].

Seed viability is usually assessed by means of a standard germination test which is time consuming and is not possible in seeds with under developed embryo, or possessing some dormancy, or hard seed coat, and in the conditions not favorable for germination [14]. TTC test offers an alternative for quick seed viability tests. High percentage of seed germination (80\%) on Annona cherimola Mill. was reported earlier on medium supplemented with $8.67 \mu \mathrm{M} \mathrm{GA3}$ [15]. In the present study, control set of seeds failed to germinate and GA3 promote in vitro seed germination. In the medium with high concentration of GA3 rapid seedling growth was also noted.

\section{CONCLUSION}

The present study showed that hard wood cuttings are most suitable material for the propagation of Colubrina travancorica, compared to softwood cuttings and seeds. The vegetative propagation methods and in vitro seed germination for $C$. travancorica demonstrated in the present study provide various options for the multiplication and conservation of this endemic plant species.

\section{ACKNOWLEDGMENT}

We are thankful to Dr. Mathew P. Joseph (Principal) and Dr. Philippose Omman (Head, Department of Botany), Catholicate College, Pathanamthitta for providing facilities and University Grants Commission, New Delhi, India, for the financial support (MRP (S)/13-14/KLMG016/UGC-SWRO).

\section{REFERENCES}

[1] N.Sasidharan, "Biodiversity documentation for Kerala. Parts 6: Flowering Plants". Handbook No.17, Kerala Forest Research Institute, Peechi, pp. 1-702, 2004.

[2] M.C.Johnston, "Revision of Colubrina asiatica (Rhamnaceae)". Brittonia, Vol.23, No. 1, pp. 2-53, 1971.

[3] D.F. Austin, "Ethnobotany of Florida's Weedy Vines". In: Jones TD, Gamble WB. (eds): Proceedings of the 1998 joint symposium of the Florida Exotic Pest Plant Council and the Florida Native Plant Society, Florida, pp. 87-88, 1999.

[4] R.A. Uphoff, A.M. Van Den Maagdenberg, K.I. Roon, M.D. Ferrari, R.R. Frantus, "The impact of pharmacogenetics for migraine". European Journal of Pharmacology, Vol. 9, pp. 1-10, 2001.

[5] N.A. Kar, M.K. Menon, C.S. Chauhan, "Pharmacological investigations of the essential oil of Colubrina asiatica". Planta Medica, Vol.18, pp. 222-226, 1970.

[6] C. McCormick, "Colubrina asiatica (Lather leaf) management plan". South Florida Water Management District West Palm Beach, Florida, pp. 1-63, 2007.

[7] T. Murashige, F. Skoog, "A revised medium for rapid growth and bioassay with tobacco tissue cultures". Plant Physiology, Vol. 15, No.3, pp. 473-497, 1962.

[8] N. Joseph, E.A. Siril, G.M. Nair, "A comparison of conventional cloning options for annatto (Bixa orellana L.) ". Journal of Horticultural Science and Biotechnology, Vol. 86, No. 5, pp. 446$451,2011$.

[9] C.L. Rosier, J. Frampton, B. Goldfarb, F.A. Blazich, F.C. Wise, "Gowth stage, auin type, and concentration influence rooting of stem cuttings of Fraser Fir". HortScience, Vol. 39, No. 6, pp. 1397-1402, 2004. 
[10] T.C. Keisling, D.E. Kester, "Aluminum and manganese toxicity of rose plants growth in East Texas". Horticultural Science, Vol. 14, pp. 509-10, 1979.

[11] G. Lal, P.K.. Roy, Y.V. Singh, "Effect of rooting and sprouting behavior of stem cuttings of Henna (Lawsonia inermis)". The Indian Journal of Agricultural Science, Vol. 18, pp. 12-15, 2008.

[12] J.S. Wazir, "Effect of NAA and IBA on rooting of Camellia cuttings". International Journal of Agricultural Science and Vetinary Medicine, Vol. 2, No. 1, pp. 1-5, 2014.

[13] F.J. De Anders, F.J. Sanchez, G. Catalan, J.L. Tenorio, L. Ayerbe, "Vegetative propagation of Colutea istria Mill. from leafy stem cuttings". Agroforestry Systems, Vol. 63, pp. 7-14, 2004.

[14] A. Modi, A. Kandya, "A study in the viability of Butea monosperma seeds ". International Journal of Scientific Research in Biological sciences, Vol. 4, No. 6, pp. 8-10, 2017.
[15] I.M.G. Pandilla, C.L. Encina, "In vitro germination of Cherimoya (Annona cherimola Mill.) seeds". Scientia Horticulturae, Vol. 97, No.1-3, pp. 224-227, 2003.

\section{AUTHORS PROFILE}

Dr. Nisha Joseph was awarded M.Phil and Ph.D degree in Botany by University of Kerala. She is currently working as Assistant Professor in the Department of Botany, Catholicate College, Pathanamthitta, Kerala. Mr. Vineeth V.K. Completed his M.Sc. degree in Botany from Catholicate College, Pathanamthitta. 